\title{
Identification and Characterization of 16SrIX and 16SrXI groups of phytoplasmas associated with leaf yellows and declining diseases of garlic and onion in India
}

\author{
SONIA GOEL ${ }^{1}$, MADHUPRIYA ${ }^{1}$, VIPOOL THORAT ${ }^{2}$, AMIT YADAV $^{2}$ and G.P. RAO ${ }^{\text {* }}$ \\ ${ }^{1}$ Division of Plant Pathology, Indian Agricultural Research Institute, Pusa Campus, New Delhi 110012 , India \\ ${ }^{2}$ National Centre for Microbial Research (formerly, Microbial Culture Collection), National Centre for Cell Science, Pashan, Pune \\ 411 021, Maharashtra, India
}

Received: 27 April 2017/ Accepted: 29 June 2017/ Published online: 24 July 2017

(c) Indian Phytopathological Society 2017

\begin{abstract}
Leaf yellows and declining symptoms were observed on garlic and onion plants at Pune and Nasik region of Maharashtra, and Gorakhpur region of Uttar Pradesh in March-April 2016. The disease incidence varied from 12\% to $30 \%$ in different surveyed regions. After nucleic acid extraction and nested PCR analysis using phytoplasma specific primer pairs (P1/P7 followed by 3F/3R) of a 16S ribosomal gene an expected DNA fragments of $1.3 \mathrm{~kb}$ were amplified in two symptomatic onion samples (from Gorakhpur and Narayangaon) and one symptomatic garlic sample (from Pune). Pair wise sequence comparison of $16 S$ rRNA gene of the onion leaf yellows phytoplasma (GKP strain) showed $100 \%$ sequence identity with a strain of phytoplasma associated with sugarcane grassy shoot disease (KP746932) and 99\% sequence identity with phytoplasma strain associated with Jasminum sambac little leaf disease (KF728950) and Ca. P. oryzae (AB052873) belonging to rice yellow dwarf (16SrXI) group. However, another strain of onion leaf yellows phytoplasma (Narayangaon strain) and garlic leaf yellows and declining phytoplasma (Pune strain) showed $99 \%$ sequence identity with phytoplasma strains of grapevine yellows (KX011516), eggplant big bud (JX464672) and sesame phyllody (JX464672) belonging to Ca. P. phoenicium (16SrIX) group. Phylogenetic analysis of $16 \mathrm{Sr}$ RNA gene sequences of phytoplasma strains from onion and garlic in the present study confirmed their close relationships with phytoplasma strains of $16 \mathrm{SrXI}$ and $16 \mathrm{SrIX}$ groups. This is the first report of association of $16 \mathrm{SrXI}$ and $-\mathrm{IX}$ groups of phytoplasma causing leaf yellows and declining disease of onion and garlic in India.
\end{abstract}

Keywords: 16SrIX, 16SrXI, garlic, onion, phytoplasma, India

Onion (Allium cepa L.) and garlic (Allium sativum L.) are the most important crops used as vegetables and culinary commodities in India. India is the second largest producer of both onion and garlic in the world after China. Onion is grown in 1.1 million hectares with the production of 18.9 million tons and productivity of 16.13 ton/ha, whereas garlic is grown in 0.2 million hectares with production of 1.4 million tons and productivity of 5.44 ton/ha. Maharashtra is the leading state in onion production after Uttar Pradesh and Orissa, whereas Madhya Pradesh is the major garlic producing state followed by Gujarat and Uttar Pradesh in India (Anonymous, 2015).

The onion and garlic crops are attacked by many diseases caused by fungi, bacteria, viruses and nematodes, which vary from region to region, season to season and variety to variety (Schwartz and Mohan, 2007). These diseases can affect the production and marketing with low quality and reduce the yield (Chand and Kumar, 2016). Phytoplasmas were first discovered in 1967 and were named mycoplasma-like organisms or

${ }^{*}$ Corresponding author: gprao_gor@ rediffmail.com
MLOs (Doi et al., 1967). They are not-yet-cultivated prokaryotic microorganisms that cause several hundred diseases of various plants (Bertaccini et al., 2014) and are transmitted by phloem-feeding leafhoppers and plant hoppers (Weintraub and Beanland, 2006). Phytoplasma diseases are increasingly important worldwide, with a high economic impact on crop production and quality (Bertaccini et al., 2014). In India, both the onion and garlic crops are severely infected by Allexivirus causing serious economic losses in India (Kumar et al., 2010). Till date, no report is available on phytoplasma incidence on onion and garlic in India. However, Phytoplasma infection in onion causing yellow dwarf disease have been reported worldwide and two phytoplasma groups, 16Srl (Lee et al., 2003; Namba et al., 1993; Vibio et al., 1995; Jung et al., 2012; Gungoosingh- Bunwaree et al., 2010) and 16SrXII (Gungoosingh-Bunwaree et al., 2010) have been reported. Besides, 16Sr III group was reported to be associated with garlic decline disease in Argentina (Galdeano et al., 2009) and 16Srl group in the USA (Mollov et al., 2014). In the present study, attempts were made to identify phytoplasma etiology associated with leaf yellows and declining disease of onion and garlic in two states (Uttar Pradesh and Maharashtra) of India. 


\section{MATERIALS AND METHODS}

Symptomatic samples (5 each) of onion and garlic plants were collected from farmer's fields of Narayangaon (Nasik, Maharashtra), Gorakhpur (U.P.) and experimental fields of Directorate of Onion and Garlic Research, DOGR (Pune, Maharashtra) India. Total genomic DNA from asymptomatic and symptomatic leaves of the onion and garlic was extracted by CTAB method (Ahrens and Seemuller, 1992) and amplification of phytoplasma ribosomal DNA (rDNA) was performed with the universal phytoplasma primer pairs P1/P7 (Deng and Hiruki, 1991; Schneider et al., 1995) followed by nested primer pair 3F/3R (Manimekalai et al., 2010). The DNA from periwinkle infected with toria phyllody phytoplasma (group 16SrIX) (Azadvar et al., 2009) maintained in the greenhouse was used as positive control and DNA extracted from asymptomatic onion and garlic samples and distilled water were used as negative controls.

PCR reactions were carried out in a Mastercycler (Eppendorf, Germany) and the cycling protocol used for the first round PCR was with initial denaturation at $94^{\circ} \mathrm{C}$ for $5 \mathrm{~min}$, followed by 35 cycles consisting of denaturation at $94^{\circ} \mathrm{C}$ for $45 \mathrm{sec}$, annealing at $55^{\circ} \mathrm{C}$ for $1 \mathrm{~min}$ and extension at $72^{\circ} \mathrm{C}$ for $2 \mathrm{~min}$, with a final extension for 10 $\mathrm{min}$. Two $\mu \mathrm{l}$ of the product of the first round of PCR were used in nested PCR assays with internal primer pairs $(3 F / 3 R)$. The reaction mixture and conditions of nested PCR were similar to those applied in the first PCR round except for the annealing temperature which was done at $63^{\circ} \mathrm{C}$. The PCR products were subjected to electrophoresis in a $1.0 \%(\mathrm{w} / \mathrm{v})$ agarose gel, stained with good view dye and observed under UV transilluminator.

An amplified product was purified using the Nucleospin Gel and PCR Clean-up kit (Macherey Nagel, Germany) and sequenced directly in both directions using the same primers as for the PCR amplification.
The sequences were aligned using CLUSTAL W method of Bio-Edit software. The consensus sequences were submitted to GenBank and used in the BLAST search analysis. The $16 \mathrm{Sr}$ DNA sequence generated from the present study and the reference phytoplasma strains sequences retrieved from GenBank were used to construct phylogeny through MEGA 6.0 version software (Tamura et al., 2013) employing the neighbor joining method with default values and 1,000 replications for bootstrap analysis. Acholeplasma laidlawii was used as the out-group to root the tree. The similarity coefficient was calculated for each pair of phytoplasma strains through BioEdit online software.

\section{RESULTS AND DISCUSSION}

Phytoplasma suspected symptoms of leaf yellows, tip necrosis, drying and declining were observed on garlic and onion plants grown in experimental plots of Directorate of Onion and Garlic Research, DOGR (30 percent incidence, Pune, Maharashtra) and farmers' fields of Gorakhpur (Uttar Pradesh) (12 per cent incidence); and Narayangaon (Nasik, Maharashtra) (15 per cent incidence) (Fig. 1a-e). The symptomatic onion and garlic plants were stunted with the reduced size of bulbs.

The universal primer pair P1/P7 did not amplify the expected DNA products of $1.8 \mathrm{~kb}$ in the first round of PCR assays. In a nested PCR assay, amplicons of 1.3 $\mathrm{kb}$ were amplified with $3 \mathrm{~F} / 3 \mathrm{R}$ primer pair in symptomatic samples of garlic and onion from all the three locations (Fig. 2). No amplifications were observed in any of the asymptomatic samples of onion and garlic collected from healthy fields from the three locations and in water controls.

Amplified DNA products from two onion (Gorakhpur and Narayangaon) and one garlic (Pune) samples were

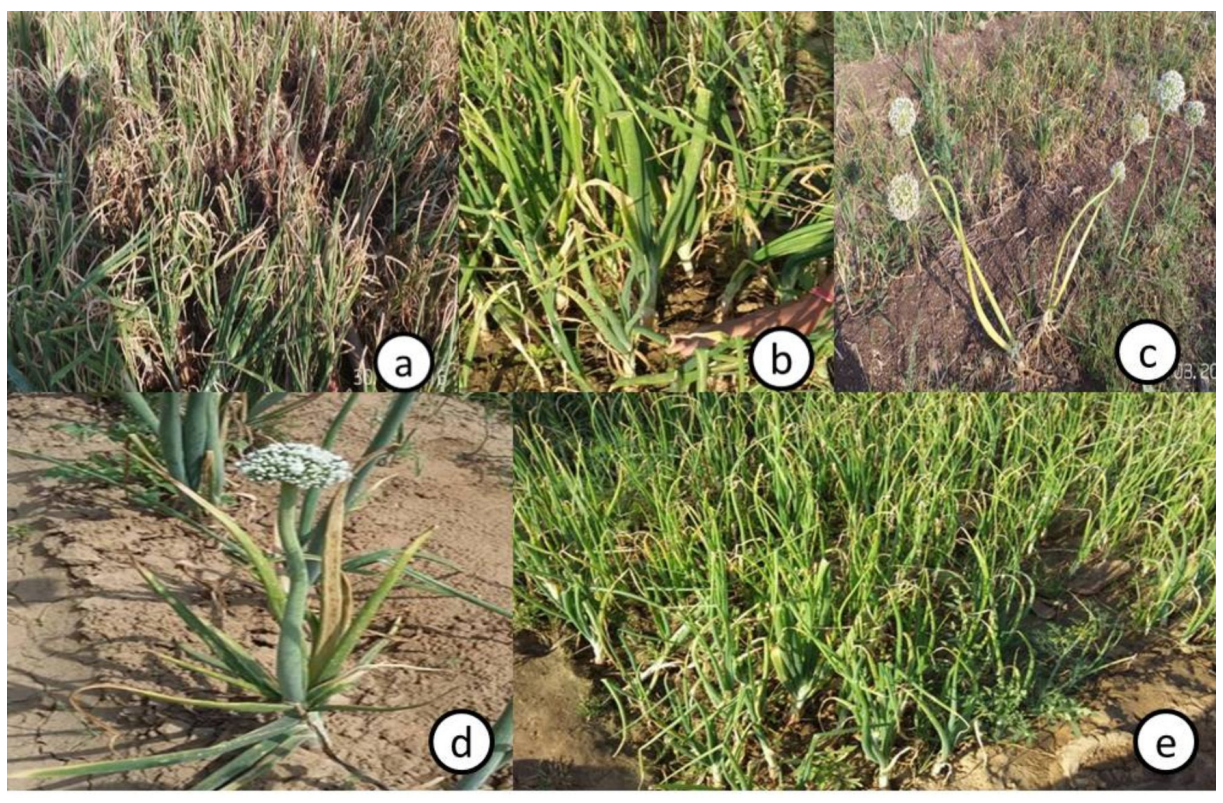

Fig. 1. Phytoplasma symptoms showed (a) leaf yellows and declining in garlic (Pune), (b \& c) leaf yellows in onion var. Phursungi (Narayangaon), (d \& e) leaf yellows in onion (Gorakhpur) 


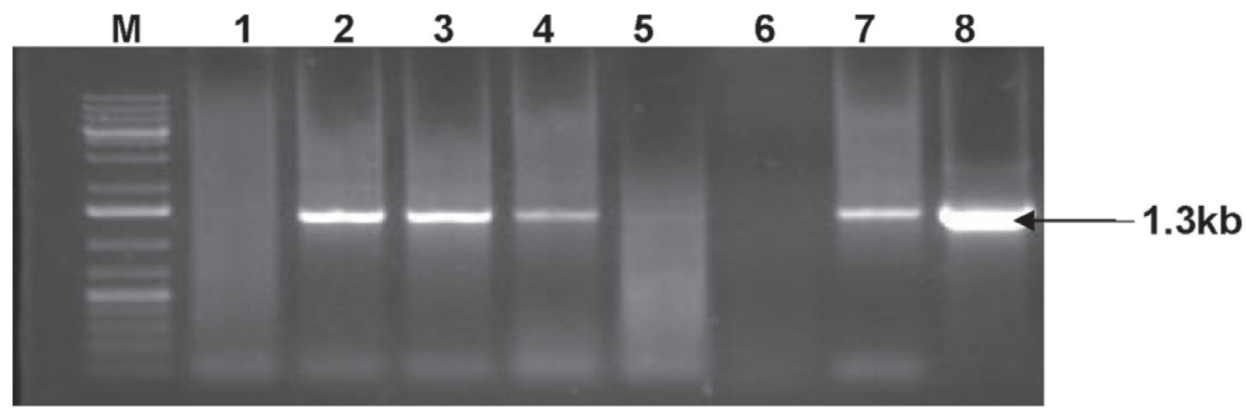

Fig. 2. Amplification of a $16 \mathrm{~S}$ rDNA product using primer pair 3F/3R (1.3kb) from onion and garlic samples. Lane M: 100bp DNA marker; Lanes 1: Asymptomatic onion sample; Lane 2 and 3: Symptomatic onion (Gorakhpur); Lane 4 and 5: Symptomatic onion var. phursungi (Narayangaon); Lane 6: Asymptomatic garlic sample; Lane 7: Symptomatic garlic (Pune); Lane 8: Positive control (toria phyllody phytoplasma)

sequenced and the consensus sequences were submitted in GenBank (Acc. No. KX641074 (onion, GKP), KX641075 (onion, Narayangaon) and KX641076 (garlic, Pune) (Table 1). Pair wise sequence comparison of $16 \mathrm{~S}$ rDNA sequence analysis of the onion leaf yellows phytoplasma (GKP strain) showed 100 per cent sequence identity with the strain of sugarcane grassy shoot phytoplasma (KP746932) and 99 per cent sequence identity with strains of Jasminum sambac little leaf phytoplasma (KF728950) and $\mathrm{Ca}$. P. oryzae (AB052873) belonging to rice yellow dwarf (16SrXI) group. However, 16S rDNA sequences of another onion leaf yellows var. phursungi phytoplasma strain from Narayangaon and the garlic leaf yellows and declining phytoplasma Pune strain showed 99 per cent sequence identity with phytoplasma strains of grapevine yellows (KX011516), eggplant big bud (JX464672) and sesame phyllody (JX464672) belonging to pigeon pea witches' broom (16SrIX group) (Table 2). Phylogenetic analysis based on 16S rDNA sequences of the onion and garlic phytoplasma strains in the present study again revealed their close relationships with members' strains of 16SrIX and $16 \mathrm{SrXI}$ phytoplasma groups (Fig. 3). The similarity coefficient calculation was performed using the $16 S r R N A$ sequences of all the three strains of onion and garlic phytoplasma in the present study and the reference strains of $16 \mathrm{SIX}$ and $16 \mathrm{SrXI}$ group. The results showed that the onion yellows phytoplasma-Gorakhpur strain shared $<97 \%$ similarity coefficient with the representative strains of $16 \mathrm{SrXI}$ groups (Table 2), indicating the association of $\mathrm{Ca}$. P. oryzae. However, the onion leaf yellows phytoplasma - Narayangaon strain and garlic leaf yellows and decline phytoplasma- Pune strain shared
$<97 \%$ similarity coefficient with the representative strains of $16 \mathrm{SrlX}$ groups, hence identified as the strain of $\mathrm{Ca}$. $P$. phoenicium (Table 2).

Several phytoplasma diseases causing various types of symptoms and damage to a variety of economically important vegetable and spice crops have been reported in India (Rao et al., 2017). 'Ca. P. asteris' (16Srl-A subgroup) was reported infecting onion and garlic crops in Canada (Khadhair et al., 2002), 16Srl-A and -L subgroup phytoplasma association with onion in Lithuania (Jomantiene et al., 2010) and 16Srl-B subgroup and 16SrXII group in onion from Mauritius (GungoosinghBunwaree et al., 2010). Besides, 16Sr III group was reported to be associated with garlic decline disease in Argentina (Galdeano et al., 2009) and 16Srl group in USA (Mollov et al., 2014). This indicates wider genetic diversity of phytoplasma associated with garlic and onion crops all over the world. The association of many groups and subgroups of phytoplasmas also indicate the susceptibility of these crops to many phytoplasma strains of different groups, which may be possible by natural spread of phytoplasma strains through efficient leafhopper vectors (Bertaccini et al., 2014). Till date, no report is available on phytoplasma incidence on onion and garlic from any region of India. In the present study, it has been confirmed the association of two groups (16SrXI and -IX) of phytoplasmas with onion and garlic from two major onion/garlic growing states (Maharashtra and Uttar Pradesh) of India. This is the first report of association of $16 \mathrm{SrXI}$ and IX groups of phytoplasma causing leaf yellows and declining disease of onion and garlic in India.

Table 1. Symptoms, location, disease incidence, phytoplasma identification of onion and garlic samples

\begin{tabular}{|c|c|c|c|c|c|c|}
\hline Plants & $\begin{array}{l}\text { Time of } \\
\text { survey }\end{array}$ & $\begin{array}{l}\text { Location } \\
\text { (Place/State) }\end{array}$ & Symptoms & $\begin{array}{l}\text { Disease } \\
\text { incidence } \\
(\%)\end{array}$ & $\begin{array}{l}\text { PCR results with } \\
\text { GenBank Acc No. } \\
\text { identified }\end{array}$ & $\begin{array}{l}\text { Phytoplasma } \\
\text { group }\end{array}$ \\
\hline Onion & April 2016 & Gorakhpur (Uttar Pradesh) & Leaf yellows & 12 & +ve (KX641074) & $16 \mathrm{SrXI}$ \\
\hline $\begin{array}{l}\text { Onion } \\
\text { (var. Phursungi) }\end{array}$ & March 2016 & $\begin{array}{l}\text { Narayangaon (Nasik, } \\
\text { Maharashtra) }\end{array}$ & Leaf yellows & 15 & +ve (KX641075) & 16SrIX \\
\hline Garlic & March 2016 & DOGR (Pune, Maharashtra) & $\begin{array}{l}\text { Leaf yellows and } \\
\text { declining }\end{array}$ & 30 & +ve (KX641076) & $16 \mathrm{SrIX}$ \\
\hline
\end{tabular}


Table 2. Sequence similarities based on 16S rRNA gene sequences of the onion leaf yellows phytoplasma (GKP strain, KX641074; Narayangaon strain, KX641075) and garlic leaf yellows and declining phytoplasma (Pune strain, KX641076) with representatives of 16Sr IX and -XI phytoplasma groups

\begin{tabular}{|c|c|c|c|c|c|c|c|c|c|}
\hline Acc. No./group & 1 & 2 & 3 & 4 & 5 & 6 & 7 & 8 & 9 \\
\hline KX641074 (ACLY) & 1.00 & & & & & & & & \\
\hline KX641075 (ACLY) & 0.941 & 1.00 & & & & & & & \\
\hline KX641076 (ASLY) & 0.942 & 0.999 & 1.00 & & & & & & \\
\hline KX011516 (GYP) & 0.942 & 0.997 & 0.998 & 1.00 & & & & & \\
\hline JX464669 (EBBP) & 0.942 & 0.997 & 0.998 & 0.998 & 1.00 & & & & \\
\hline JX857827 (Ca.P. Phoenecium) & 0.944 & 0.997 & 0.998 & 0.998 & 0.998 & 1.00 & & & \\
\hline AF248957(PPWB) & 0.945 & 0.992 & 0.993 & 0.993 & 0.993 & 0.995 & 1.00 & & \\
\hline AB052873 (Ca. P. oryzae) & 0.984 & 0.938 & 0.939 & 0.939 & 0.939 & 0.941 & 0.943 & 1.00 & \\
\hline KP746932 (SCGS) & 1.00 & 0.941 & 0.942 & 0.942 & 0.942 & 0.944 & 0.945 & 0.984 & 1.00 \\
\hline
\end{tabular}

For each pair wise alignment, the similarity (relative to the maximum similarity) and the number of identical nucleic acids (in \% of shorter sequence) is given. ACLY (Allium cepa leaf yellows), ASLY (Allium sativum leaf yellows), GYP (Grapevine yellows phytoplasma), EBBP (Eggplant Big bud phytoplasma), Ca. P. Phoenecium (Candidatus phytoplasma phoenicium), PPWB (Pigeon pea Witches'broom), Ca. P. oryzae (Candidatus phytoplasma oryzae), SCGS (Sugarcane grassy shoot phytoplasma).

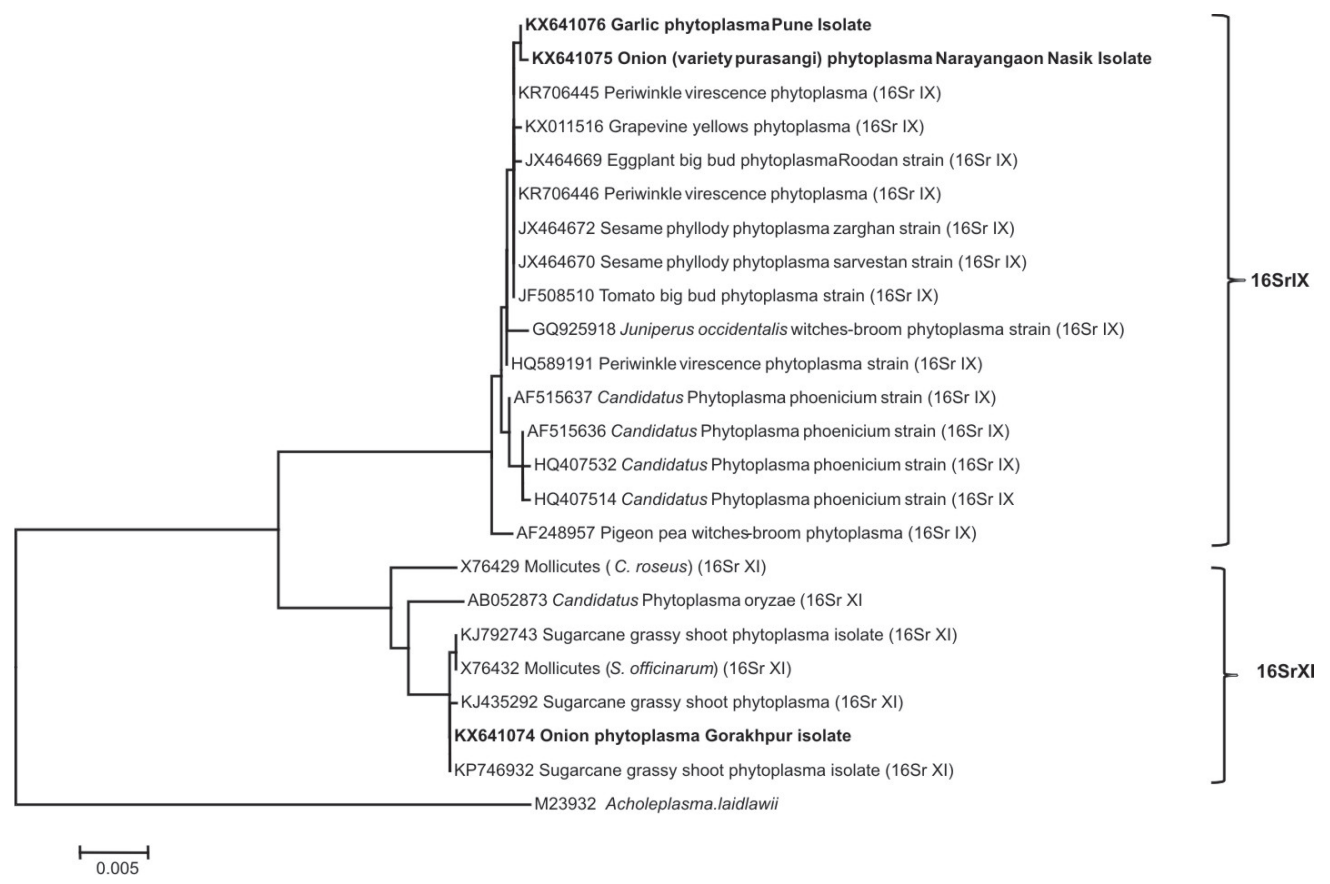

Fig. 3. Phylogenetic tree constructed by neighbor-joining method showing the relationships between onion and garlic phytoplasmas strains (black highlight) and reference phytoplasmas strains based on the nucleotide sequences of $16 S$ rRNA gene sequence fragment. A. laidlawii was used as an out group

Ca. P. oryzae $(16 \mathrm{Sr} \mathrm{XI})$ has been reported associated with important phytoplasma diseases of sugarcane, rice, areca nut and coconut, however, the Ca. P. phoenicium was reported to infect pigeon pea, toria and ornamentals in India (Rao et al., 2017). Leafhopper vectors are already known to transmit Ca. P. oryzae in nature in India (Rao et al., 2014; Tiwari et al., 2017). Hence it would be quite possible that both the reported phytoplasma strains may spread in nature by efficient leafhopper species to other important crop and thus has great potential in causing serious economic losses to many crops in India.

\section{ACKNOWLEDGEMENTS}

The authors are thankful to ICAR, New Delhi for providing ICAR Platform Research funding and Head, Division of
Plants Pathology, IARI, New Delhi for providing laboratory facilities. Authors are also acknowledged this funding support by SERB, New Delhi through the Project No. SERB/F/9182.

\section{REFERENCES}

Ahrens U and Seemuller E (1992). Detection of DNA of plant pathogenic mycoplasma like organisms by a polymerase chain reaction which amplifies a sequence of the $16 \mathrm{~S}$ rRNA gene. J. Phytopathol. 82: 828-832.

Anonymous (2015). DOGR Annual Report 2014-2015. ICARDirectorate of Onion and Garlic Research Rajguru nagar, Pune, Maharashtra, India.

Azadvar M, Baranwal V K and Yadava D K (2009). First report of a 16SrlX (Pigeon pea witches' broom) phytoplasma 
associated with toria (Brassica rapa cv. toria) phyllody disease in India. New Dis. Rep. 20: 27.

Bertaccini A, Duduk B, Paltrinieri S and Contaldo N (2014). Phytoplasmas and phytoplasma diseases: a severe threat to agriculture. Am. J. Plant. Sci. 5: 46-62.

Chand G and Kumar S (Eds.) (2016). Crop Diseases and Their Management: Integrated Approaches. Apple Academic Press, Canada. pp. 188-190.

Deng S and Hiruki C (1991). Amplification of 16S rRNA genes from culturable and nonculturable Mollicutes. J. Microbiol. Methods 14: 53-61.

Doi Y, Teranaka M, Yora K and Asuyama H (1967). Mycoplasmaor PLT group-like microorganisms found in the phloem elements of plants infected with mulberry dwarf, potato witches' broom, aster yellows, or Paulownia witches' broom. Ann. Phytopathol. Soc. Japan 33: 259-266.

Galdeano E, Conci L R, González O, Paradell S, Di Rienzo J A, Nome C. and Conci V C (2009). Epidemiological aspects of garlic decline disease caused by a phytoplasma in Asiatic and Argentinean garlic cultivars. Aust. PI. Pathol. 38: $437-443$.

Gungoosingh-Bunwaree A, Contaldo N, Vally V, Benimadhu SP, Duduk B and Bertaccini A (2010). Detection of phytoplasmas in watercress and onion plants from Mauritius. Plant Health Prog. 10: 1094.

Jomantiene R, Davis RE, Lee IM, Zhao Y, Bottner-Parker K, Valiuna, D and Petkauskaite R (2010). Onion is host for two phytoplasma lineages, subgroups $16 \mathrm{Srl}-\mathrm{A}$ and $16 \mathrm{Srl}$ (-B/L) L, in Lithuania: A Hinfl site revealed a SNP marking divergent branches of evolution. J. Plant Pathol. 92: 461470 .

Jung H Y, Win N K K and Kim Y H (2012). Current status of phytoplasmas and their related diseases in Korea. Plant Pathol. J. 28: 239-247.

Khadhair A H, Evans I R and Choban B (2002). Identification of aster yellows phytoplasma in garlic and green onion by PCR-based methods. Microbiol. Res. 157: 161-167.

Kumar S, Baranwal VK, Joshi S, Arya M and Majumder S (2010). Simultaneous detection of mixed infection of Onion yellow dwarf virus and an Allexivirus in RT-PCR for ensuring virus free onion bulbs. Indian J. Virol. 21: 64-68.

Lee IM, Martini M, Bottner KD, Dane RA, Black MC and Troxclair $\mathrm{N}$ (2003). Ecological implications from a molecular analysis of phytoplasmas involved in an aster yellows epidemic in various crops in Texas. Phytopathology 93: 1368-1377.

Manimekalai R, Soumya VP, Kumar RS, Selvarajan R, Reddy K, Thomas GV, Sasikala M, Rajeev G and Baranwal VK (2010). Molecular detection of $16 \mathrm{SrXI}$ group phytoplasma associated with root (wilt) disease of coconut (Cocus nucifera) in India. Plant Dis. 94: 636.

Mollov D, Lockhart B, Saalau-Rojas E and Rosen C (2014). First report of a 16Srl (Aster yellows) group phytoplasma on garlic (Allium sativum) in the United States. Plant Dis. 98: 419-419.

Namba S, Kato S, Iwanami S,Oyaizu H, Shiozawa $\mathrm{H}$ and Tsuchizaki T (1993). Detection and differentiation of plantpathogenic mycoplasma like organisms using polymerase chain reaction. Phytopathology 83: 786-791.

Rao GP, Madhupriya, Thorat, V, Manimekalai R, Tiwari AK and Yadav A (2017). A century progress of research on phytoplasma diseases in India. Phytopathogenic Mollicutes, 7(1): 1-38.

Rao GP, Madhupriya, Tiwari AK, Kumar S and Baranwal VK (2014). Identification of sugarcane grassy shoot-associated phytoplasma and one of its putative vectors in India. Phytoparasitica 42: 349-354.

Schneider B, Seemueller E, Smart CD and Kirkpatrick BC (1995). Phylogenetic classification of plant pathogenic mycoplasma-like organisms or phytoplasmas. In: S. Razin, and J. G. Tully (eds.), Molecular and Diagnostic Procedures in Mycoplasmology. Academic Press, San Diego, California, USA. Vol. 1: 369-380.

Schwartz HF and Mohan SK (2007). Compendium of onion and garlic diseases and pests. (Ed. 2). APS Press, ISBN 9780-89054-357-3, USA. pp. 127.

Tamura K., Stecher G, Peterson D, Filipski A and Kumar S (2013). MEGA6: molecular evolutionary genetics analysis version 6.0. Mol. Bio. Evol. 30: 2725-2729.

Tiwari AK, Kumar S, Mall S, Jadon V and Rao GP (2017). New efficient natural leafhopper vectors of sugarcane grassy shoot phytoplasma in India. Sugar Tech. 19: 191-197.

Vibio M, Camele I, Bertaccini A, Rana GL, D'Aloisio V and Benni A (1995). Metodi diagnostici molecolari per l'individuazione di infezioni fitoplasmatiche in cipolla. L'Inf. tore Agrario 35: 75-77.

Weintraub PG and Beanland L (2006). Insect vectors of phytoplasmas. Ann. Rev. Entomol. 51: 91-111. 